\title{
The Innovation Mechanism and Path for Green Development of Exhibition Industry
}

\author{
Xiu-Li LIU* \\ Wuhan Business University, Wuhan City, Hubei Province, China \\ Xiuli92@126.com \\ ${ }^{*}$ Corresponding author
}

\begin{abstract}
Keywords: Exhibition industry, Innovation mechanism, Green development.
\end{abstract}
\begin{abstract}
China's economy is showing a new normal, turning from high speed growth to medium and high speed growth. The economic structure is confronted optimization and upgrading. The driving force of economy is changed from factor drive, investment drive to innovation drive. The exhibition industry of our country has developed rapidly in recent years, but there are also some problems in the development. This paper mainly discusses how to realize the green development of the exhibition industry. Starting from the innovation mechanism of the green development of exhibition industry, it is considered that the green development of exhibition must break the traditional extensive development path and find a new innovative mechanism such as technological innovation, organization innovation, service innovation, system innovation, idea innovation and mechanism innovation. And the paper puts forward the implementation path of green development of the exhibition industry, that is to strengthen technological innovation, develop intensively exhibition industry, optimize industry chain of exhibition, to perfect the green supervision mechanism for exhibition industry and establish, perfect standards and evaluation system for green development exhibition industry etc..
\end{abstract}

\section{Introduction}

The exhibition industry in China is developed continuously and rapidly and the annual exhibition area has been in the forefront of the world. Our country has become a veritable great country of exhibition. According to the 2016 China exhibition data statistics report of the Exhibition Economy Research Association, years, the total number of national exhibitions increased from 7330 to 9892 in 2011-2016, increasing by $34.95 \%$, the exhibition area increased from 81.6 million $\mathrm{m} 2$ to 130.75 million $\mathrm{m} 2$, with a growth rate of $60.23 \%$. Compared to 2015 , the exhibition total growth is $6.6 \%$, total exhibition area increased by $10.8 \%$ in 2016. The rapid development of China's exhibition industry is mainly reflected in extensive growth. It is worth considering how to transform and upgrade, optimize the structure and cultivate brand exhibition under the new normal. Although the exhibition industry is regarded as a smokeless industry, but the background of extensive long-term development, with the increase of the number and scale of the exhibition, some problems have arisen such as serious pollution of the exhibition site, large consumption of resources and energy, low utilization rate of exhibition halls. These problems have brought great distress to the organizers, exhibition halls and exhibition service. It is urgent to promote the transformation and upgrading of the exhibition industry, to realize green development of exhibition industry.

Green development is a mode innovation on the basis of traditional development and based on the constraint of environmental capacity and carrying capacity of resources. It takes environmental protection as a new development model to achieve sustainable development. The green development of exhibition industry is a model that takes efficiency, harmony, sustainable development as goals and to develop exhibition industry with the idea of sustainable development in order to realize low carbon, saving, environmental protection and safety of exhibition industry. Since 1990s, with the growing concern of the international community on environmental issues and the formation of the idea of sustainable development, the mature exhibition industry countries of European and American are increasingly concerned about the green development of the industry. 
China's 2008 Green Olympics and the 2010 Shanghai Expo have played a leading and exemplary role for the green development of China's exhibition industry. The green development of exhibition industry has also been gradually concerned.

Innovation, green and development are the themes of the times. In order to achieve green development, exhibition industry must break the traditional model of extensive development and find new innovation mechanism. Technology innovation is the footstone of the exhibition industry development, organization innovation is the carrier of green development of the exhibition industry, service innovation is the booster to promote green development of exhibition industry, the idea innovation is the inner force of green development, system innovation is the external power of green development and mechanism innovation is an important guarantee for the green development of the exhibition industry.

\section{Necessity Analysis for Green Development of Exhibition Industry}

\section{The Green Development of the Exhibition Industry Is the Need to Respond to the National Policy}

Facing the rapid development of China's exhibition industry and the problems, "Some suggestions on further promoting the reform and development of the exhibition industry" released by State Council of China fully affirms the function of the development of China's exhibition industry, but also clearly defines economy, society, culture, ecological function of the exhibition industry. The document has pointed out the global goals for China's exhibition industry. These are to advocate the idea of low carbon, environmental protection and green and to foster and strengthen the main body of the, to accelerate the exhibition industry transformation and upgrading, to promote the development of China from the big exhibition industry to the strong exhibition industry, to better serve the national economy and social development.

\section{The Green Development of the Exhibition Industry Is the Need for the Sustainable Development}

With the gradual deterioration of the ecological environment, people realize the importance of sustainable development. In the process of production and consumption, more and more attention is paid to the protection of resources and environment. At the time of the exhibition, the exhibition booth is one of the core elements of an exhibition, but the design of the exhibition booth is a serious waste of resources at present. In exhibition booth design, in order to show their strength to be different in the exhibition or to achieve profit, some exhibitors and some exhibitors use special booth. This results in many companies use a special booth the exposition and luxury decoration in special booth will cause environmental pollution. An exhibition is generally extended for 3 to 5 days. The removed material after exhibition, especially the special booth, basically cannot be reused. This leads to a lot of waste of manpower, material and financial resources, at the same time causes serious environmental pollution. For a long time, material pollution in exhibition, low recycling rate after exhibition display and a lot of waste the is detrimental to sustainable development of exhibition industry.

\section{Green Development Is the Need for the Transformation and Upgrading of the Exhibition Industry}

China's exhibition industry has been developed rapidly and has become a big country of exhibition. Although the exhibition industry is a smoke-free industry, the environmental pollution and resource waste caused by some exhibition sites is shocking in some exhibition from the green index. Data show that the area of garbage generated in the exhibition will account for $50 \%$ of the total exhibition area. Therefore, there is such a metaphor in the exhibition industry, that is the end of a exhibition is the birth of a garbage dump. To conduct technological innovation, use environmental and recycled materials in exhibition booth building and find sustainable development system, service model and institution which is more suitable for exhibition are not only urgent for upgrading 
China's exhibition industry, but also are the inevitable choice to promote China's exhibition industry from a big country to a power and to participate in international competition.

\section{The Innovation Mechanism and Path for the Green Development of the Exhibition Industry \\ Technological Innovation Is the Footstone of the Green Development of the Exhibition Industry}

To avoid the serious pollution caused by the materials used in the exhibition booth, we should increase the strength of scientific and technological innovation in booth design. In the innovation of exhibition booth material, the "3R principles" should be embodied. The first is reduction principle. Green materials are used as much as possible in the design of the booth so as to reduce the use of toxic and radiant materials. In the booth design, we should simplify the construction process of the hall and develop materials with little waste in dismantling booth. The second is reuse principle. Because exhibition industry has characteristics such as short cycle and repeated exhibition, removability, recyclability and reusability in booth design should be considered. Renewable and reusable materials should be used in the building of the booth. For example, standard parts are used to set up booth. These parts can be dismantled after an exhibition and can be used at the next exhibition so as to achieve the purpose of reuse. The third is recycling principle. As the final waste, it can be used as raw material again into the production of new products. Technological innovation is the footstone of the green development of exhibition industry. Relevant state departments should take measures to encourage service providers of exhibition engineering to increase technological innovation and develop green and environmental exhibition booth materials.

\section{Organizational Innovation Is the Carrier of the Green Development of the Exhibition Industry}

Intensively Develop Exhibition Industry to Promote Resource Conservation. The intensive development of exhibition industry is to use modern management and technology centrally and rationally and give full play to the positive effect of human resources based on the full use of all resources so as to improve work effectiveness and efficiency. There are two forms of the intensive development of the exhibition industry. The first is to form industrial cluster by numerous related exhibition enterprises based in the specialization principle, The second is the joint exhibition model. The intensive development of the exhibition industry is to optimize and integrate resources. This can share the good of the external economy. Firstly, the cost advantage can be obtained. The enterprises with intensive development can share all kinds of infrastructure, public service facilities, information resources, market network and commonly use some auxiliary services in order to save cost. For example, joint publicity can be conducted and cost can also be saved by using of joint exhibition model. Exhibitor can share on-site services such as exhibits logistics service, exhibition booth building services, catering services and transport services. Secondly, intensive development can develop external economy. It has be shown by highly specialized enterprise collaboration in exhibition intensive external economy and every enterprise undertake activities in exhibition chain. This makes small and medium-sized enterprises can develop scale economy and attract more customers.

The Optimal Combination of the Exhibition Industry Chain. The overall core competition ability of the exhibition industry can be enhanced by optimizing the exhibition industry chain and improving entirely the service quality of the exhibition industry. Chinese exhibition industry development report (2016) introduced China (Chongqing) International Intelligent Manufacturing Technology and Equipment Expo created a new model of the exhibition industry chain. Under the Expo flag, 5 exhibition are held simultaneously and exhibition area is $80000 \mathrm{~m} 2$. Visitors is more than 60000 people. The Expo is an exhibition mode innovation and industrial chain exhibition which is the first market operation exhibition in China. The Expo is ranging complete upstream and downstream industry chain from material processing, parts production, host manufacturing to user services. It can provide more comprehensive services for customers, reduce the marketing 
procurement cost of enterprises, set up a cooperation and communication platform for enterprises of the upstream and downstream in 5 different industry chain exhibition.

\section{Service Innovation Is the Booster for Promoting the Green Development of the Exhibition Industry}

As a third industry, the service quality level of exhibition industry directly affects customer satisfaction. Therefore to improve service quality is of great significance for promoting healthy development of exhibition industry. However, the exhibition industry in China started late and is in the period of rapid development, but the exhibition service has always been a big weakness in the exhibition industry. In order to survive in a fierce market competition environment and set up an international brand, exhibition enterprises must improve their service quality, optimize their service processes and fundamentally change their business models and service ideas so as to remain invincible in international competition.

\section{System Innovation Is the External Motive Force of the Green Development of the Exhibition Industry}

Establishment of Relevant Institutions to Promote the Green Development of the Exhibition Industry. Led by Circulation Industry Promotion Center of China's Commerce Ministry in 2016, 53 entities related to exhibition industry jointly initiated in Beijing to launch the establishment of a China Green Exhibition Alliance. The purpose of the alliance is to build green exhibition ecosystem, achieve scientific, technological innovation and convenient management of exhibition industry, improve the level of information, intelligence and intensification, reduce costs of exhibition operation and management, environmental pollution, energy consumption and accelerate the development of green exhibition. The alliance is the first cooperation platform of green exhibition industry led by government departments and participated in by leading enterprises with green environmental protection idea in the exhibition industry chain. On this platform, the alliance will aggregate related resources and power of exhibition organizers, the exhibition hall and the exhibition service and promote the construction of standard system, relevant policies support, the popularization of green idea, green materials and its technical application and model innovation of management service and innovation in order to realize the linkage of green exhibition industry chain.

Improving the Green Supervision Mechanism of the Exhibition and Promoting the Green Development of the Exhibition Industry. We should strengthen the environmental supervision for the exhibition and punish the waste of resources, the environment pollution and the ecology destruction by law. We should establish supervision mechanism of green exhibition, establish and improve the environmental monitoring system in the exhibition activities, monitor timely the impact of exhibition activities on the environment, strengthen the supervision for the exhibit design, exhibition arrangement and activities, and conduct one vote veto system that does not meet the requirements of environmental protection. Simultaneously, we should establish an ecological red line management system in order to force exhibitor eliminate high pollution materials in exhibition design and exhibition arrangement to achieve green development.

Promote the Third Party Certification Work of Green Exhibition. Third party certification of green exhibition refers to the third party management institution or social organization but owners and customers of the exhibition project, verify exhibition projects or exhibition enterprises in accordance with the relevant green standards and determine that the management system of the exhibition or exhibition enterprise is in conformity with the green standard.

\section{Strengthening the Idea Innovation of the Public is the Internal Motive Force of the Green Development of the Exhibition Industry}

The 18th Chinese Communist Party Congress puts forward to strengthen the construction of ecological civilization. People's thinking determines the action. In the whole society, we should strengthen the cultivation of social public's idea of ecological civilization and firmly establish the idea of ecological civilization. If the exhibition organizers, exhibitors, audience and all kinds of 
exhibition service providers have awareness of ecological civilization, low-carbon, green, environmental protection, saving, green exhibition will be taken as a conscious action. To cultivate the ecological civilization idea of public, the some measures can conducted, including publicity of ecological civilization idea in the whole society, integration the ecological civilization education into the national education system, training of green exhibition for employees of exhibition industry.

\section{Mechanism Innovation Is an Important Guarantee for the Green Development of the Exhibition Industry}

Formulating Laws and Regulations to Promote the Green Development of the Exhibition Industry. In order to reduce the waste of large exhibition resources and the pollution to the environment, a common measure adopted by developed countries and international organizations is to establish green conference (exhibition) guide documents and implement "green exhibition plan". This requires the organizers, exhibitors and audiences of the exhibition strive to meet the requirements of the green conference guide in order to reduce carbon emissions and protect the environment. China should also establish and improve the exhibition environmental protection system, and make compulsory regulations to promote development of the exhibition enterprises in the green direction.

Taking Incentive, Evaluation and Benchmarking Measures to Promote the Green Development of the Exhibition Industry. In exhibition process, exhibition organizers can take the following incentive measures to guide the implementation of exhibition industry in order to realize green development. Firstly, rewards and punishment system can be conducted in the policy guidance. Financial subsidies can be given to enterprises that use low carbon technology and products in the process of exhibiting. Warning and punishment are given to enterprises that exceed carbon emissions in exhibition process. Secondly, green grading is carry out. In order to encourage exhibitors to achieve the requirements of saving, green and environmental protection in booth design, the exhibition organizers can evaluate the booth of exhibitor. These enterprises that conform to green requirement and utilize reasonably exhibition space are rewarded. Thirdly, benchmarking measures promote green development of exhibition industry. Taking good exhibition organizers, exhibition project, exhibitors, booth design as industry benchmarks can promote the publicity and promotion of green exhibition. Development of the exhibition industry can be conducted by reward, evaluation and setting up benchmarks.

To Plan the Exhibition Industry So As to Promote the Rational Utilization of Resources. According to survey statistics of the Chinese exhibition industry development report (2016), China has built 286 professional exhibition halls, the total area is $8.9289 \mathrm{~m} 2$ and has become a veritable big exhibition. But in general, the operation of the exhibition hall is not satisfactory and the economic benefits are not optimistic. According to "2015 China Exhibition economic development report" of China Council for the Promotion of International Trade, the rent rate of exhibition halls over $50 \%$ is 6 and in the $30-50 \%$ is 15 . The rental rate of most of the exhibition halls is below $30 \%$ and lower than operating breakeven point of the exhibition halls, that is in operating losses state. Many exhibition halls only hold a few exhibitions and activities throughout the year, even for a long time. There is a serious surplus of construction capacity of exhibition hall in China, which urgently needs to be macroscopically controlled and guided. It can be seen from the data that the construction of the exhibition halls in China is not reasonable. This results in the waste of resources. Therefore, the development of the exhibition industry needs to be macroscopically planned and guided by the government.

\section{Conclusions}

To achieve the green development of exhibition industry, we must break the traditional extensive development path, carry out technological innovation, organizational innovation, service innovation, system innovation, idea innovation and mechanism innovation. China's exhibition industry should be developed intensively, optimize the exhibition industry chain, improve the green supervision 
mechanism of exhibition industry, establish and perfect the green development standard and evaluation system of exhibition.

\section{References}

[1] Chen Yi-ping. Problems and Measures on China's Green MICE Industry Development. International Business Research, 2011(2).

[2] Ren Shenggang, Yuan Baolong. Driving Force for the Green Development of Industry in the Yangtze River Economic Belt.Reform, 2016(7).

[3] zhang Xiaoming, Liang He. The ecological responsibility of the government in the ecological process of exhibition industry. 2015(1).

[4] Gao Min. China green exhibition alliance is established. China trade news, June 7, 2016, The 005th.

[5] Cai Meng,GRIESE Kai-Michae,TANG Jia-ni. A Review of International Green Event in Concept and Practices . Journal of SU IBE, 2015(7).

[6] Pan Jianjun. the 2016 China exhibition data statistics report . the Exhibition Economy Research Association, In April 2017.

[7] Xiuli Liu. Analysis of the exhibition industry from the perspective of ecological civilization. Pioneering with Science \& Technology Monthly, 2014(7). 